Gabriela Frischke

Wydział Historyczny, Uniwersytet Kazimierza Wielkiego w Bydgoszczy

Dział Historii Medycyny i Farmacji, Muzeum Okręgowe im. Leona Wyczółkowskiego w Bydgoszczy

ORCID 0000-0003-3373-6850

Roksana Wilczyńska

Sekcja Historii Farmacji, Oddział Bydgoski, Polskie Towarzystwo Farmaceutyczne

Wojciech Ślusarczyk

Wydział Nauk o Zdrowiu, Collegium Medicum im. Ludwika Rydygiera w Bydgoszczy Uniwersytetu Mikołaja Kopernika w Toruniu

Dział Historii Medycyny i Farmacji, Muzeum Okręgowe im. Leona Wyczółkowskiego w Bydgoszczy

ORCID 0000-0002-0517-5518

\title{
Wyposażenie „PRL-owskiej” izby recepturowej ze zbiorów Muzeum Okręgowego im. Leona Wyczółkowskiego w Bydgoszczy. Genius loci czy suma przypadków?
}

\author{
Equipment of a Prescription Room from the Polish People's \\ Republic Times in the Collection of Leon Wyczółkowski \\ District Museum in Bydgoszcz. Genius loci or the Sum \\ of Cases?
}

In 2017, the Leon Wyczółkowski District Museum in Bydgoszcz purchased the collection of a private pharmacy museum, previously functioning in the back of the now-liquidated Pod Łabędziem ('Under the Swan') pharmacy in Bydgoszcz, first opened in 1853. Among the acquired museum exhibits, there is prescription room equipment from the Polish People's Republic period. From the point of view of museum workers and researchers of pharmaceutical material culture, in order to learn more about the acquisitions, it is essential to answer the following questions: Where and when were the prescription furniture and their equipment produced? Were they used only in Pod Łabędziem ('Under the Swan') pharmacy? Is the room equipment complete? What can the preserved equipment tell us about the type of drugs produced there? The conducted analysis allows us to state that the prescription furniture were manufactured in Nowe nad Wisłą at the turn of the 1970s. 
The prescription room is an original component of the described pharmacy but preserved in a truncated form. Its location is secondary. Chaos reigns among the preserved utensils. The current state of affairs does not reflect the standards of work in the former community pharmacy. The sum of the cases prevails over the genius loci.

Keywords: pharmacy, prescription room, museology

Słowa kluczowe: aptekarstwo, farmacja, receptura apteczna, muzealnictwo

27 lipca 2017 r. Muzeum Okręgowe im. Leona Wyczółkowskiego (dalej: MOB) dzięki dotacji celowej Urzędu Miasta Bydgoszczy zakupiło zabytkową aptekę „Pod Łabędziem”, której początki sięgają połowy XIX w.

Jej historia rozpoczęła się 28 kwietnia 1852 r., gdy władze pruskie ogłosiły konkurs na przyznanie koncesji umożliwiającej uruchomienie trzeciej apteki w Bydgoszczy. 27 grudnia 1853 r. wygrał go Constantin August Mentzel'1. Zapewne ze względu na to, że w mieście istniały już apteka „Pod Złotym Orłem” oraz apteka „Pod Czarnym Orłem”, nową placówkę nazwano apteką „Pod Łabędziem”.

Parcela przewidziana na aptekę znajdowała się w nowej części miasta, na początku ulicy Gdańskiej (obecnie Gdańska 5). Założenie apteki wpisywało się więc w szerszy plan rozbudowy Bydgoszczy. Dodajmy, że w 1851 r. miasto uzyskało komunikację kolejową². Apteka powstała w odległości półtora kilometra od dworca. Od drugiej połowy XIX w. miejsce to stanowi ścisłe centrum nowoczesnego miasta. Na parceli przylegającej do nowo wzniesionej kamienicy aptecznej założono ogród roślin leczniczych. W 1909 r. po rozbudowie budynku przeniesiono go na znajdujące się za nim podwórze. W dwudziestoleciu międzywojennym ze względu na rosnącą obecność na rynku gotowych preparatów produkowanych przez rozwijający się dynamicznie przemysł farmaceutyczny ogród zlikwidowano, przeznaczając go na kort tenisowy3.

W 1864 r. Mentzel określał swoją aptekę jako homeopatyczną. Z kolei w 1892 r. jego syn, Hugo Albert, reklamował ją jako alopatyczną i homeopatyczną, a także prowadzącą m.in. laboratorium do badań mikroskopowych, bakteriologicznych i chemicznych ${ }^{4}$. W tym okresie na zapleczu apteki powstało laboratorium galenowe wykonujące leki na skalę półprzemysłową․ Należy zaznaczyć, że zachowało się ono do dziś in situ w stanie nienaruszonym, stanowiąc unikat na skalę ogólnopolską.

2 K. Wajda, Przeobrażenia gospodarcze Bydgoszczy w latach 1850-1914, [w:] Historia Bydgoszczy, t. 1, red. M. Biskup, Warszawa - Poznań 1991, s. 530.

3 Apteka „Pod Łabędziem” w Bydgoszczy. 150 lat, red. A. Drygas, Bydgoszcz 2003, s. 51, 55-56. Więcej na temat intensywnego rozwoju przemysłu farmaceutycznego w: W. Ślusarczyk, D. Chyła, Przemysł chemiczno-farmaceutyczny na Kujawach i Pomorzu Gdańskim (1918/20-1950), Bydgoszcz 2017, s. 43-49.

4 Apteka "Pod Łabędziem", s. 58.

5 Laboratorium galenowe wywodzi swą nazwę od drugiego pod względem znaczenia po Hipokratesie, starożytnego, grecko-rzymskiego medyka - Klaudiusza Galena z Pergamonu (ok. 129-199 lub 200 r. n.e.), który opracował m.in. metody sporządzania leków z surowców roślinnych, zwierzęcych i mineralnych, określanych do dziś jako leki galenowe. Zob. B. Koskowski, Nauka o przyrządzaniu leków i ich postaciach, t. 2, Warszawa 1929, s. 5; G. Urdang, E. Kremers, History of Pharmacy, red. G.A. Sonnedecker, Madison 1986, s. 19-21; J. Szostak, Farmakognozja, farmacja galenowa $i$ aptekarstwo $w$ renesansowych zielnikach polskich, Warszawa 2006, s. 100. 
W trakcie II wojny światowej ówczesny właściciel apteki, Brunon Kazimierski, podpisał volkslistę i zmienił nazwisko na Kalten ${ }^{6}$. W 1945 r. apteka, jako mienie poniemieckie, została przejęta przez państwo, od którego dzierżawił ją mgr farm. Henryk Kowalewski. W 1951 r. placówka weszła pod jurysdykcję Centrali Aptek Społecznych, zyskując miano Apteki Społecznej o numerze 39. W 1971 r. jej kierownikiem została mgr farm. Łucja Wachowska. Stan powyższy utrzymał się do momentu transformacji ustrojowej.

30 października 1990 r. apteka została wykupiona przez mgr farm. Łucję Wachowską, mgr farm. Danutę Kośmider i mgr. farm. Bartłomieja Wodyńskiego ${ }^{7}$. Spółka istniała do 2003 r. 27 grudnia tego roku, w 150. rocznicę uzyskania koncesji przez Mentzla, Wodyński utworzył na jej zapleczu prywatne Muzeum Farmacji Apteki „Pod Łabędziem”, w którym znajdowało się ponad 7 tys. zabytków ${ }^{8}$. W 2017 r. aptekę i muzeum zamknięto, a całość została zakupiona przez $\mathrm{MOB}^{9}$. Kolekcją zajmuje się obecnie powołany w tym celu we wrześniu 2018 r. muzealny Dział Historii Medycyny i Farmacji. W niedalekiej przyszłości w dawnej aptece „Pod Łabędziem” zostanie otwarty oddział MOB, którego ekspozycja stała, ukazująca historię bydgoskiego aptekarstwa oraz dawne techniki wykonywania leków, będzie ważnym punktem na lokalnym, turystycznym Szlaku Wody, Przemysłu i Rzemiosła, w skrócie $\mathrm{TeH}_{2} \mathrm{O}^{10}$.

Wśród zakupionych muzealiów znajduje się między innymi, wyposażenie izby recepturowej (receptury, określanej też jako „drugi stół”) z okresu Polski Ludowej, składające się głównie z lóż recepturowych i szklanych naczyń (sztanglasów). W każdej aptece izba recepturowa do dziś, choć już w ograniczonym w zakresie, wykorzystywana jest do wykonywania leków ${ }^{11}$. W związku z tym z punktu widzenia muzealników i badaczy farmaceutycznej kultury materialnej dla poznania przejętych zabytków ważna jest próba udzielenia odpowiedzi na następujące pytania:

1. Gdzie i kiedy wyprodukowano loże recepturowe i ich wyposażenie?

2. Czy przejęte loże recepturowe były używane wyłącznie w bydgoskiej aptece „Pod Łabędziem"?

3. Czy wyposażenie loży stanowi kompletne świadectwo standardu dawnej receptury?

4. Czy zachowane wyposażenie loży może świadczyć o rodzaju wykonywanych w niej leków?

Udzielenie odpowiedzi pozwoli zweryfikować lub sfalsyfikować hipotezę mówiącą, że tytułowa receptura stanowi oryginalne, zachowane bez zmian i in situ, wyposażenie apteki „Pod Łabędziem”. Kwestia ta jest istotna, ponieważ kuratorzy przygotowywanej ekspozycji stałej zamierzają nadać jej możliwie wysoki walor autentyczności. Podjęcie badań

6 Archiwum Państwowe w Bydgoszczy, sygn. 299, Pismo notariusza Alfreda Breitkopfa z 27 lipca 1940 r.; Archiwum mgr farm. Łucji Wachowskiej [AŁW], Apteka „Pod Łabędziem” w Bydgoszczy lata 1945-1951.

7 AŁW, Kopia pisma ministra Zdrowia i Opieki Społecznej, Koncesja na prowadzenie apteki z 18 lipca 1990 r.; Kopia pisma Przedsiębiorstwa Zaopatrzenia Farmaceutycznego „CEFARM” z 3 listopada 1990 r.

8 W. Ślusarczyk, Muzeum Farmacji Apteki „Pod Łabędziem” w Bydgoszczy, „Kwartalnik Historii Kultury Materialnej" t. 53, 2005, s. 124-125; J. Majewski, Muzea farmacji i zbiory aptekarskie w Polsce, Poznań 2006, s. $87-90$.

9 Historia Medycyny i Farmacji, strona internetowa MOB, muzeum.bydgoszcz.pl/zbiory/106, 10920,0,0,Dzial-Historii-Medycyny-i-Farmacji,1 [dostęp 14.08.2019].

10 Apteka „pod tabędziem”, strona internetowa Szlaku Wody, Przemysłu i Rzemiosła $\mathrm{TeH}_{2} \mathrm{O}$, ludzieitechnika.pl/10 teh2o-apteka-pod-labedziem [dostęp 14.08.2019].

11 Obecnie w izbach recepturowych wykonuje się leki w zindywidualizowanych dawkach niedostępnych w ofercie przemysłu farmaceutycznego. 


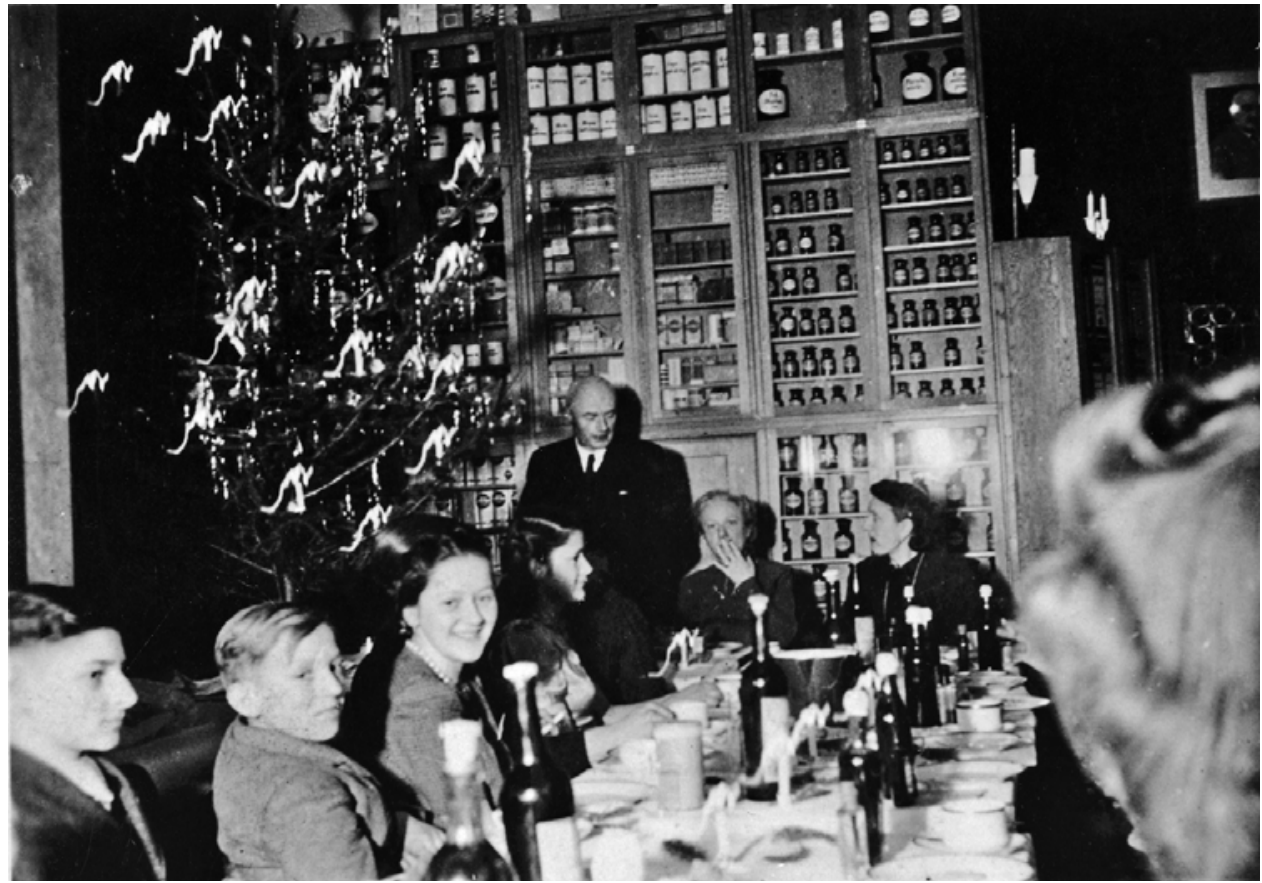

Ryc. 1. Wnętrze apteki w czasie II wojny światowej (własność Muzeum Okręgowego im. Leona Wyczółkowskiego w Bydgoszczy, nr inw. MOB MOB FM/AF-2526/6, repr. W. Woźniak)

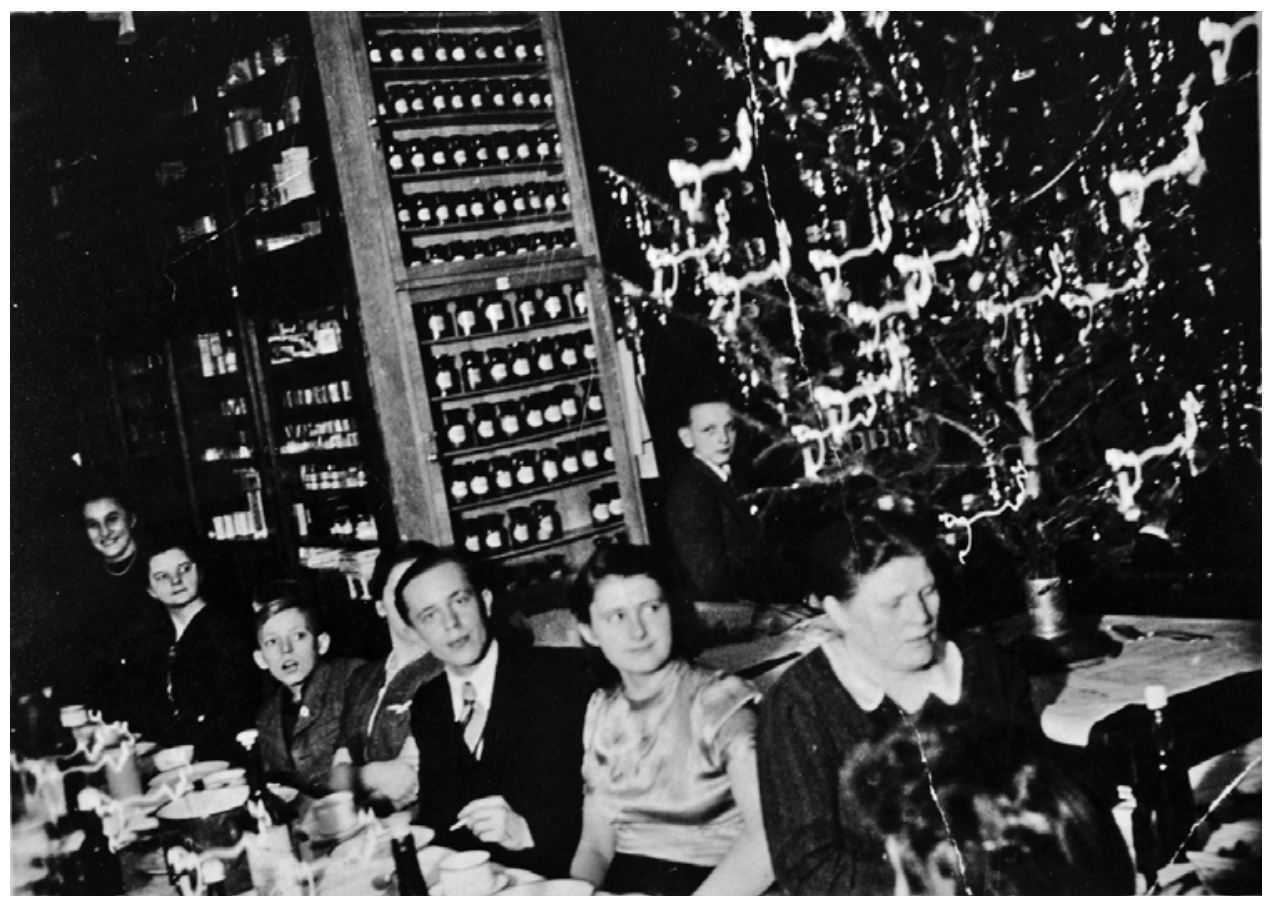

Ryc. 2. Wnętrze apteki w czasie II wojny światowej (własność Muzeum Okręgowego im. Leona Wyczółkowskiego w Bydgoszczy, nr inw. FM/AF-2526/4, repr. W. Woźniak) 


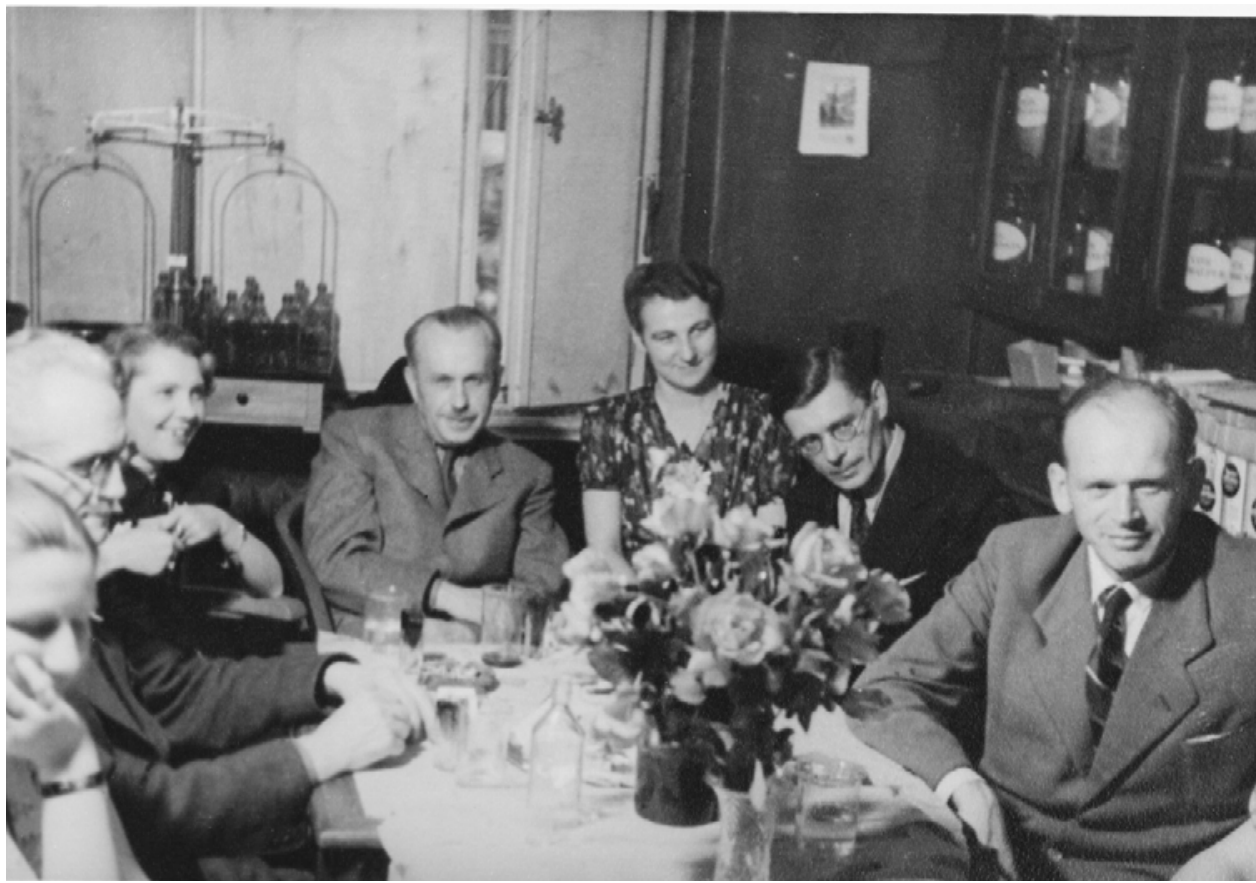

Ryc. 3. Pomieszczenie, w którym obecnie znajduje się receptura, lata pięćdziesiąte XX w. (własność Muzeum Okręgowego im. Leona Wyczółkowskiego w Bydgoszczy, nr inw. MOB FM/AF-002882 1, repr. W. Woźniak)

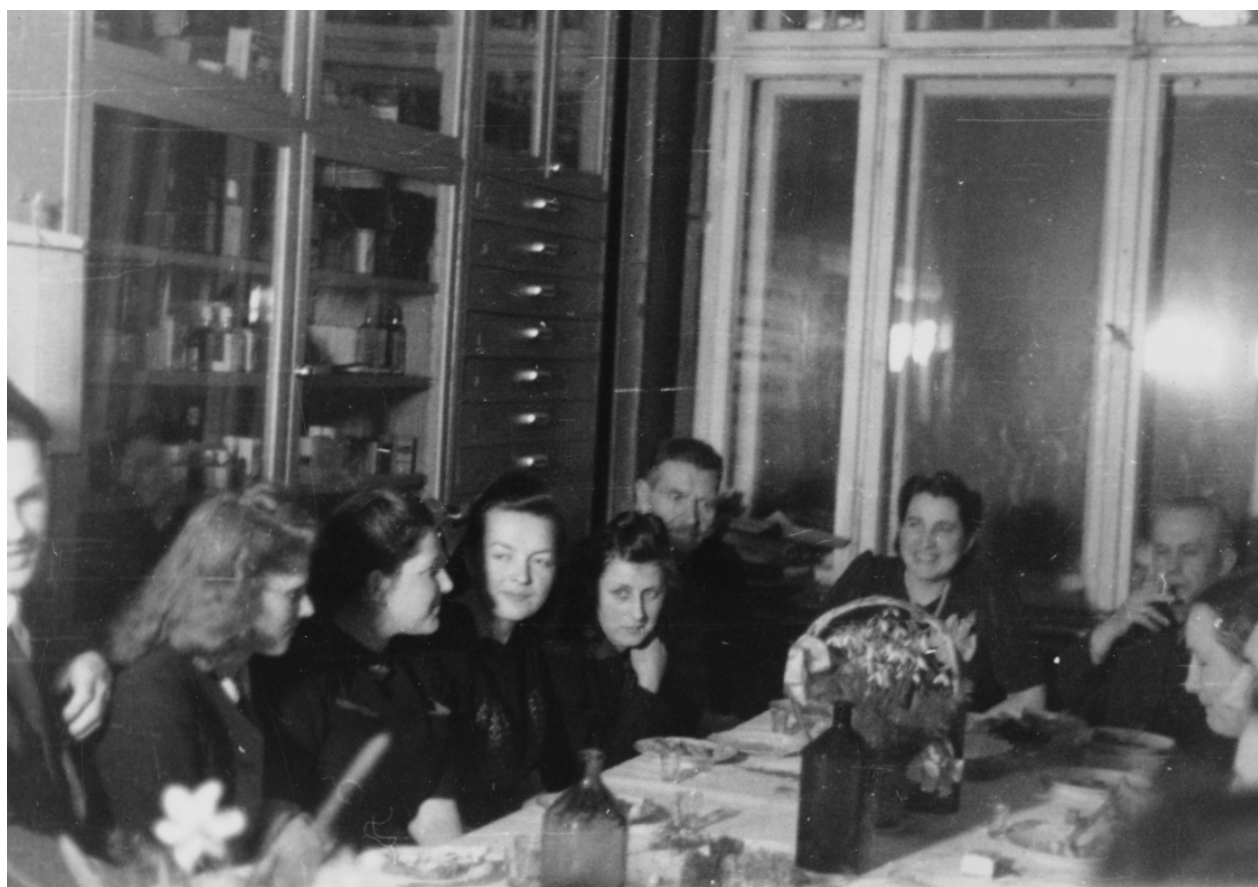

Ryc. 4. Pomieszczenie, w którym obecnie znajduje się receptura, lata pięćdziesiąte XX w. (własność Muzeum Okręgowego im. Leona Wyczółkowskiego w Bydgoszczy, nr inw. MOB FM/AF-002882 10, repr. W. Woźniak) 
w tym kierunku wynikało również z tego, że dokumentacja związana z tytułową recepturą nie zachowała się.

Pierwotnie na zapleczu apteki nie było wydzielonych pomieszczeń (oprócz laboratorium galenowego) - przestrzeń dzieliły meble. Widoczne są one na niepublikowanych zdjęciach z okresu II wojny światowej oraz z lat pięćdziesiątych XX w. (Ryc. 1 i 2) ${ }^{12}$. Meble te służyły zarówno do przechowywania surowców, jak i leków gotowych wytworzonych przez przemysł farmaceutyczny. Na fotografiach widać pomieszczenie, w którym obecnie znajduje się muzealna receptura (w środkowej części lokalu) (Ryc. 3 i 4$)^{13}$.

Sytuacja ta była zgodna z dawnymi wymogami prawnymi. W zaborze pruskim wykaz pomieszczeń, które musiały znajdować się w aptece ogólnodostępnej, był określony w Regulaminie ruchu aptecznego z 18 lutego 1902 r. Nie wspomina on o osobnej izbie recepturowej ${ }^{14}$. Czynności recepturowe wykonywano więc w dowolnej części apteki, przypuszczalnie w pobliżu izby ekspedycyjnej. Na terenie byłego zaboru pruskiego przepis powyższy obowiązywał do upaństwowienia aptek w 1951 r. Zdawano sobie przy tym sprawę, że sporządzanie leków recepturowych w odrębnej przestrzeni może przyczynić się do zwiększenia ich jakości (np. czystości mikrobiologicznej). Ze względu jednak na ograniczenia lokalowe wielu niewielkich aptek Zarządzenie ministra zdrowia w sprawie typów aptek, zakresu ich czynności, lokali i wyposażenia z 22 lutego 1956 r. dopuszczało wciąż łączenie izby recepturowej z izbą ekspedycyjną ${ }^{15}$. Osobna izba recepturowa $w$ aptekach ogólnodostępnych typu A (o powierzchni nie mniejszej niż $100 \mathrm{~m}^{2}$ ) stała się wymogiem dopiero na podstawie Zarządzenia Ministra Zdrowia i Opieki Społecznej w sprawie typów aptek, zakresu i rodzaju czynności należących do aptek poszczególnych typów oraz wymogów dotyczących lokalu i wyposażenia aptek z 13 listopada 1992 r. $^{16}$

W pierwszym ćwierćwieczu XX w. w bezpośrednim sąsiedztwie apteki funkcjonowała drogeria „Pod Łabędziem”, należąca do Brunona Kazimierskiego ${ }^{17}$. W 1950 r. kierownik apteki, mgr farm. Tadeusz Kalinowski, uzyskał zgodę na poszerzenie jej o wspomniany lokal drogeryjny. Tym samym drogeria przestała istnieć. W jej miejscu znalazła się nowa izba ekspedycyjna, a recepturę urządzono w dawnym pomieszczeniu izby ekspedycyjnej ${ }^{18}$. Obszerne miejsce, które jej przeznaczono, dowodzi znacznego zapotrzebowania na wyko-

12 Fotografie ze zbiorów Muzeum Okręgowego im. Leona Wyczółkowskiego w Bydgoszczy [MOB], MOB FM/AF2526/4, MOB FM/AF-2526/6.

13 Fotografie ze zbiorów MOB, MOB FM/AF-002882 1, MOB FM/AF-002882 7, MOB FM/AF-002882 8, MOB FM/ AF-002882 10, MOB FM/AF-002882 15, MOB FM/AF-002882 16.

14 C. Schlick, Apotheken in totalitären Staat. Apothekenalltag in Deutschland von 1937 bis 1945, Stuttgart 2008, s. 24. Wymogu posiadania przez apteki osobnego pomieszczenia przeznaczonego na recepturę nie przewidywały także przepisy obowiązujące w pozostałych zaborach. Nie wymagała go Ustawa dla farmaceutów i aptek z 21 października 1844 r. (Królestwo Polskie) oraz Ustawa aptekarska z 18 grudnia 1906 r. (zabór austriacki). Zob. Ustawa dla farmaceutów i aptek, 1844 r., rozdz. IV, § 70, [w:] Ustawy dla farmaceutów i aptek. Dla materialistów. Dla kupców ukwalifikowanych do sprzedawania wszelkiego rodzaju towarów farbiarskich, Warszawa 1844, s. 97; Austr. Dz. U. P. z 1907 r., No 5.

15 „Monitor Polski” 1956 r., Nr 18, poz. 254. Obecnie obowiązek posiadania osobnej izby recepturowej określa Rozporządzenie Ministra Zdrowia z dnia 26 września 2002 r. w sprawie wykazu pomieszczeń wchodzących w skład powierzchni podstawowej i pomocniczej apteki, Dz.U. 2002 nr 161 poz. 1338.

16 „Monitor Polski” 1992 r., Nr 37, poz. 277.

17 Apteka „Pod Łabędziem", s. 64.

18 Ibid, s. 73. 


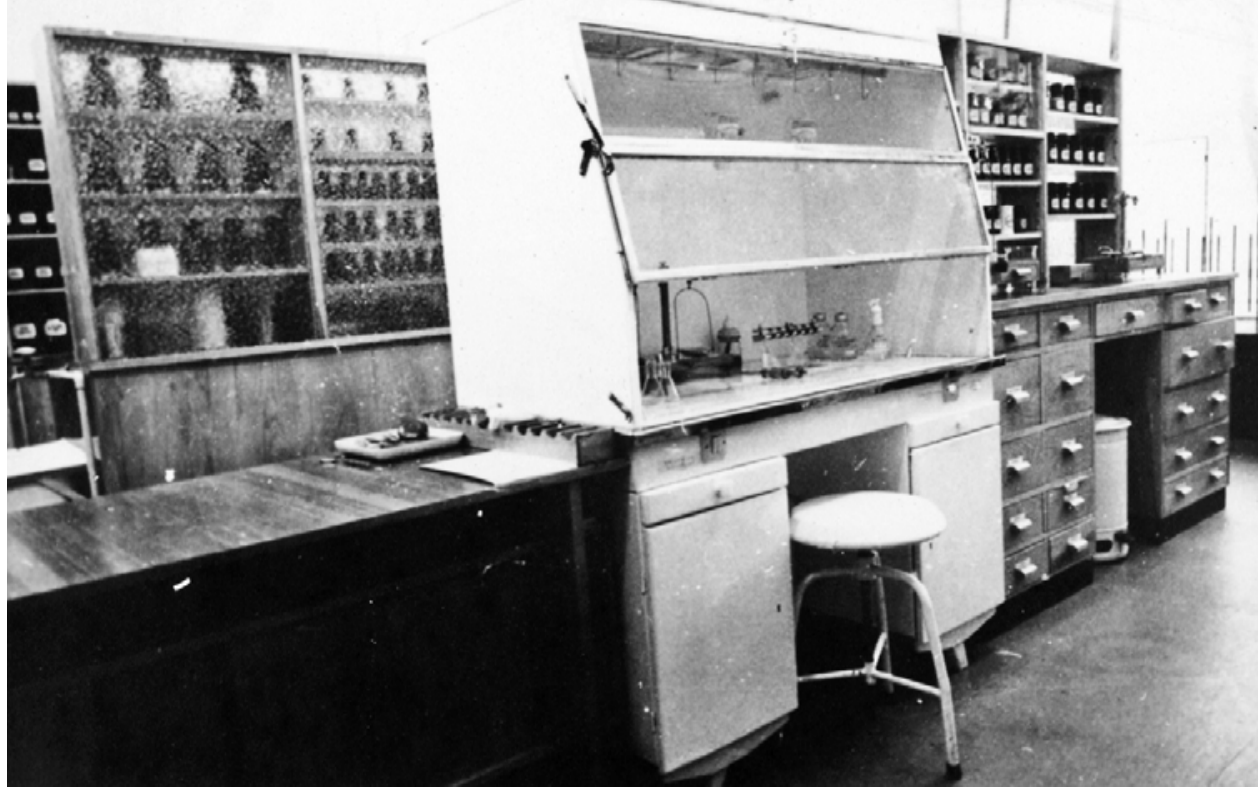

Ryc. 5. Nowe wyposażenie receptury z początku lat siedemdziesiątych XX w. (prywatne archiwum mgr farm. Łucji Wachowskiej, repr. W. Woźniak)

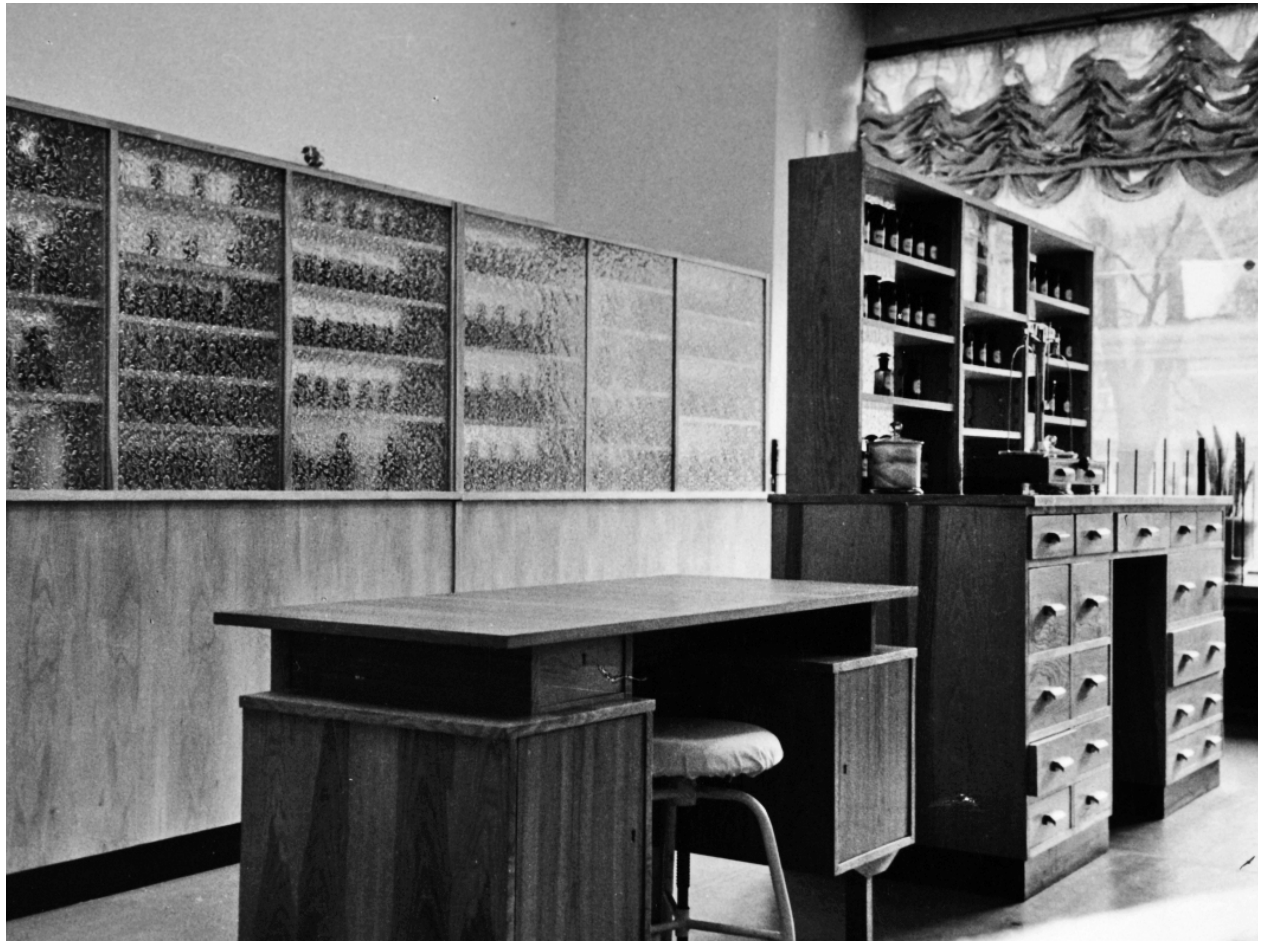

Fot. 6. Nowe wyposażenie receptury z początku lat siedemdziesiątych XX w. (prywatne archiwum mgr farm. Łucji Wachowskiej, repr. W. Woźniak) 


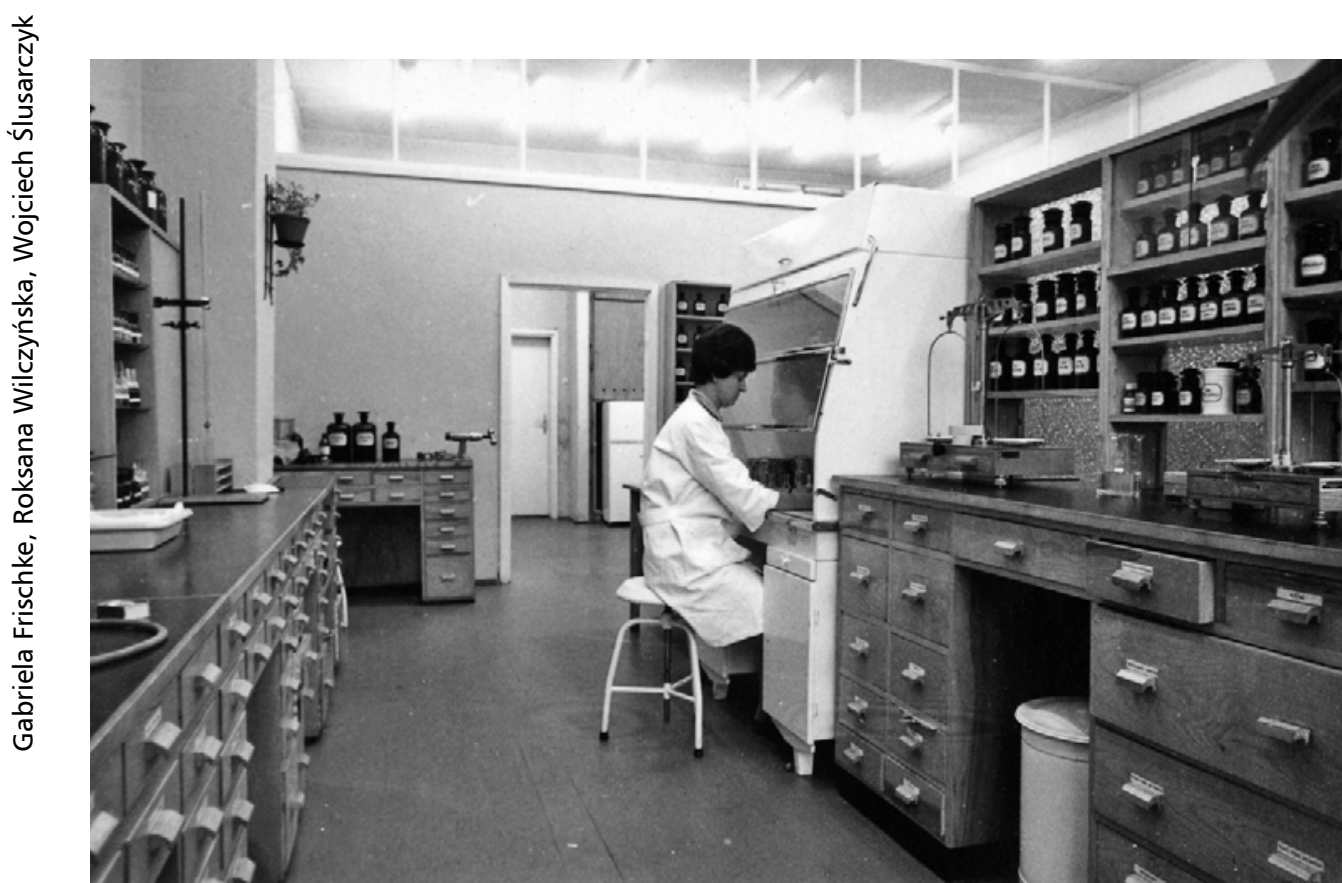

Fot. 7. Nowe wyposażenie receptury z początku lat siedemdziesiątych XX w. (prywatne archiwum mgr farm. Łucji Wachowskiej, repr. W. Woźniak)

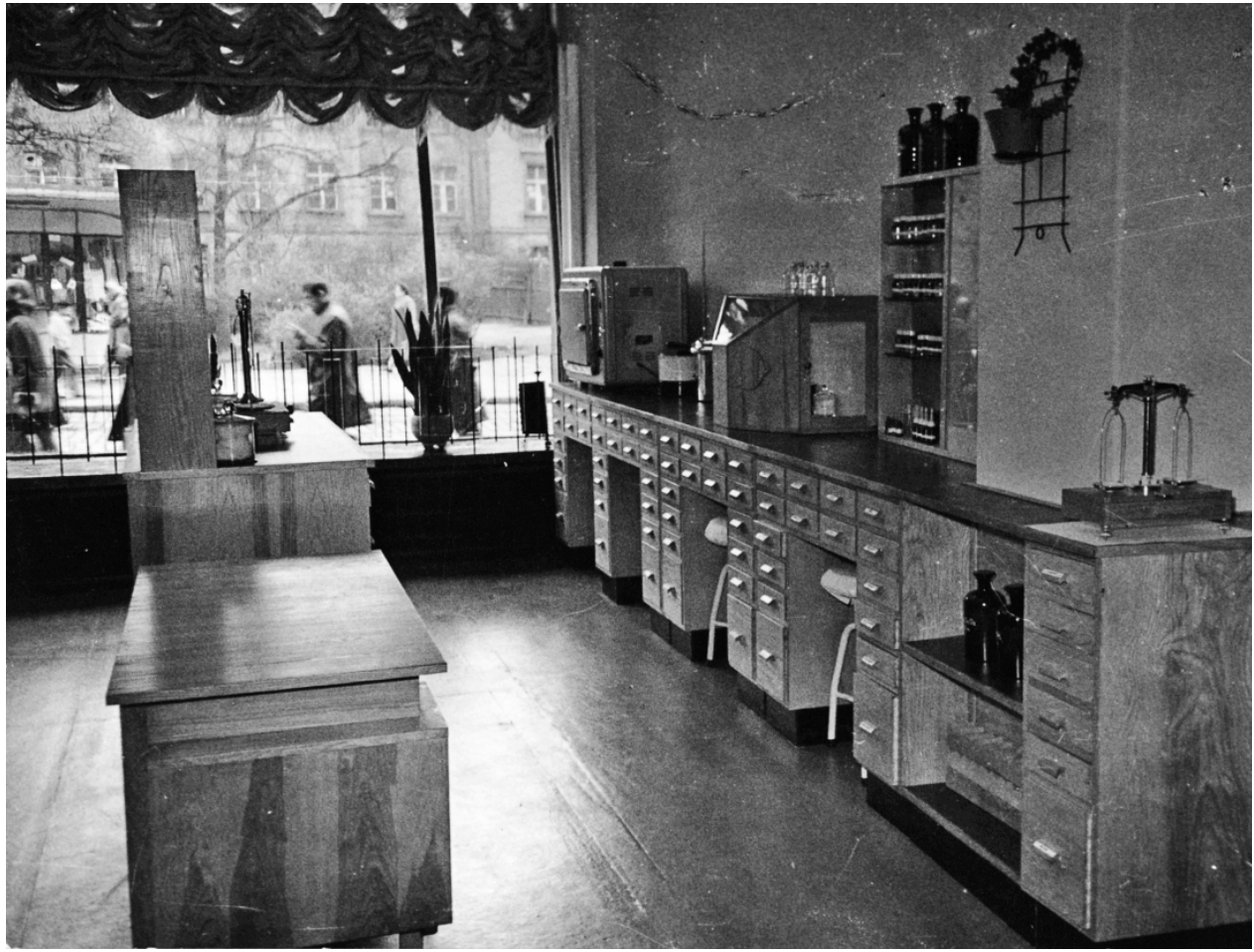

Fot. 8. Nowe wyposażenie receptury z początku lat siedemdziesiątych XX w. (prywatne archiwum mgr farm. Łucji Wachowskiej, repr. W. Woźniak) 
nywane w aptece leki. Zauważyć trzeba też, że utworzenie wydzielonej izby recepturowej wyprzedzało niejako ówczesny stan prawny, co świadczy korzystnie o postawie ówczesnego kierownictwa.

Na podstawie prywatnego archiwum Wachowskiej (zastępcy kierownika apteki w latach 1969-1971, a następnie kierownika w latach 1971-2003 ${ }^{19}$ ) można ustalić, że najpoważniejsze zmiany w układzie i przeznaczeniu pomieszczeń apteki nastąpiły na przełomie lat 1969-1970. Wówczas pod nadzorem ówczesnej kierownik, mgr farm. Janiny Majewskiej, przeprowadzono generalny remont. Przy wydzielaniu pomieszczeń kierowano się chęcią poprawy funkcjonalności lokalu oraz przeznaczeniem placówki na cele szkoleniowe. Po zakończeniu prac budowlanych do apteki wstawiono nowe wyposażenie ${ }^{20}$. Wydzieloną recepturę, znajdującą się obok izby ekspedycyjnej, wyposażono wówczas w nowe meble i sprzęt widoczny na Ryc. 5-8:

- dwie loże (tzw. proszkową i mokrą),

- lożę szkoleniową,

- szafkę aseptyczną do przygotowywania kropli do oczu,

- biurko do opisywania leków,

- stół kontrolny (z odczynnikami i niewielką ilością drobnego sprzętu),

- szafy na chemikalia,

- mały destylator,

- suszarkę,

- promiennik podczerwieni do topienia podłoży maściowych,

- mieszadło elektromagnetyczne,

- czopkarkę,

- inny drobny sprzęt recepturowy ${ }^{21}$.

Powyższe wyposażenie było typowe dla ówczesnych aptek społecznych. W zbiorach MOB znajdują się zdjęcia apteki w Lubrańcu z tego okresu, na których widoczne są niemal identyczne loże recepturowe, jak w przypadku badanych tu obiektów (Ryc. 9) ${ }^{22}$. Przejęte meble pochodzą więc z przełomu lat sześćdziesiątych i siedemdziesiątych XX w. Są pozbawione informacji o producencie. Nie zachowała się też dokumentacja towarzysząca ich zakupowi. Wiadomo jednak, że meble dla aptek w całej Polsce produkowała wówczas Zasadnicza Szkoła Drzewna w Nowem nad Wisłą ${ }^{23}$.

Działalność apteki była dość często opisywana w lokalnych gazetach. Najbardziej zwracano uwagę na jej charakter szkoleniowy oraz zabytkowe laboratorium galenowe. W 1980 r. w „Ilustrowanym Kurierze Polskim” opisano jednak również pracę w recepturze:

Codzienne obowiązki pracowników apteki nie ograniczają się do wydawania leków już gotowych [...]. Dużo czasu poświęcają oni ponadto na przekazywanie odpowiednich informacji - zarówno lekarzom jak i samym pacjentom. Bardzo pracochłonne jest też przyrządzanie leków recepturowych. Obecnie służą do tego celu

19 AŁW, Apteka „pod Łabędziem” w Bydgoszczy od 1969 r.

20 Niestety wcześniejsze, zabytkowe meble, pochodzące zapewne jeszcze z XIX w., zostały wówczas bezpowrotnie utracone.

21 AŁW, Opis pomieszczeń apteki po modernizacji w $1970 \mathrm{r}$.

22 Fotografie ze zbiorów MOB, MOB FM/AF-2737, MOB FM/AF-2735.

23 Wywiad z Zenonem Gurbadą, pasjonatem historii meblarstwa, przeprowadzony 15 VII $2020 \mathrm{r}$. 


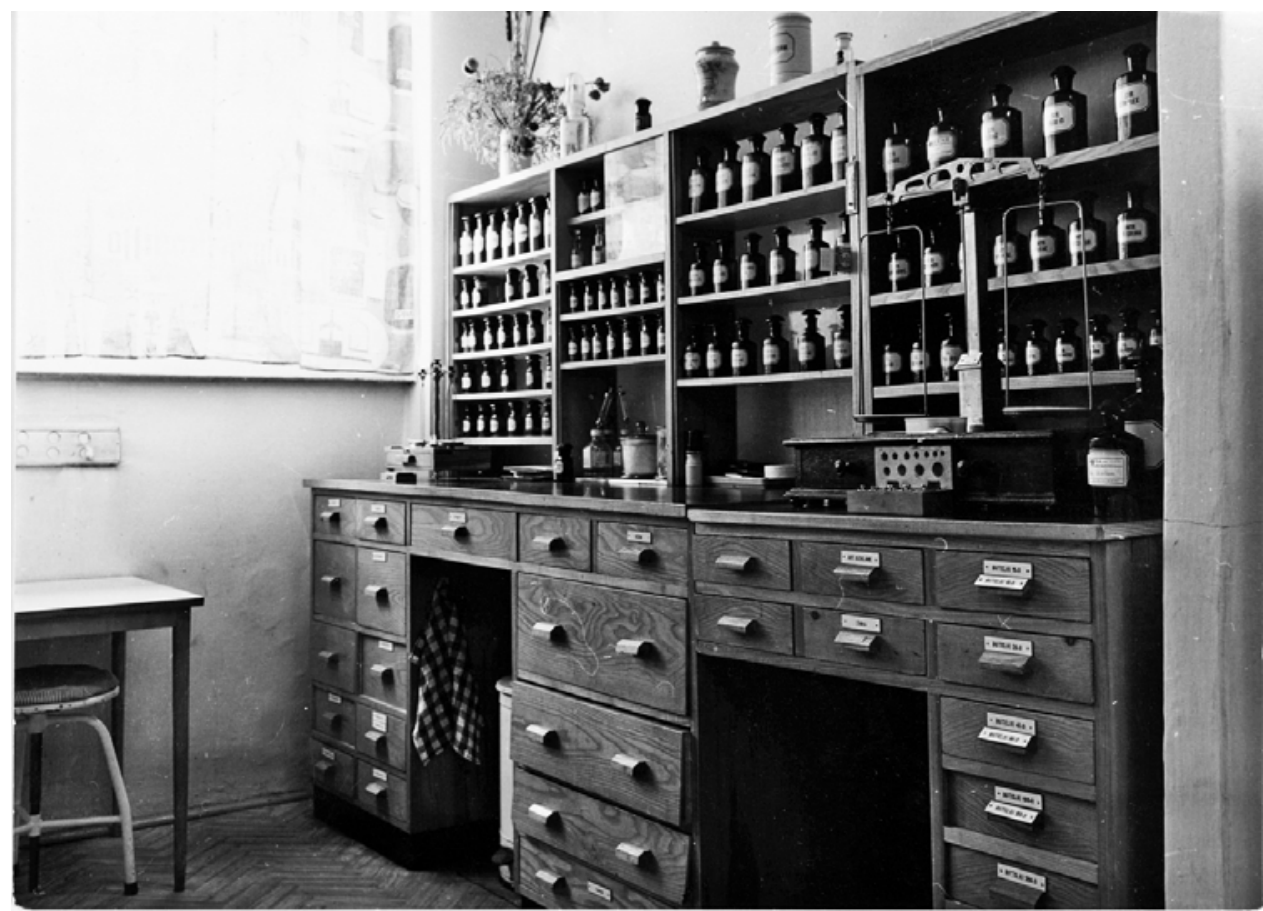

Ryc. 9. Meble recepturowe z apteki w Lubrańcu (własność Muzeum Okręgowego im. Leona Wyczółkowskiego w Bydgoszczy, nr inw. MOB FM/AF-2737, repr. W. Woźniak)

- w szczególności dla zagwarantowania właściwej jakości - najnowsze urządzenia, jak autoklaw do sterylizacji sprzętu i opakowań, loża z laminarnym nawiewem, zapewniająca warunki aseptyczne, a także waga elektryczna i inne ${ }^{24}$.

O intensywności prac świadczy też notatka statystyczna za 1987 r., w której wymieniono liczbę wykonanych recept złożonych - 23810 (w tym 11168 leków do oczu) ${ }^{25}$.

Po prywatyzacji apteki w 1990 r. nastąpiła kolejna zmiana w układzie pomieszczeń. Recepturę przeniesiono w głąb lokalu, do mniejszego pomieszczenia, a od frontu ustawiono zabytkowe meble ekspedycyjne, pochodzące z apteki „Pod Łabędziem” w Toruniu²6. Przeniesienie receptury wiązało się z ograniczeniem liczby używanych w niej mebli. Od tej pory do pracy wykorzystywano:

- dwie loże z blatami, półkami i szufladami (wys. 179,5cm, szer. $181 \mathrm{~cm}$, gł. $70 \mathrm{~cm}$ ),

- szafę na trucizny z półką i szafką przesuwną (wys. 200 cm, szer. $125 \mathrm{~cm}$, gł. 29,5cm),

- regał na puszki z szafką przesuwną (wys. 200 cm, szer. 124,5 cm, gł. 30,5 cm),

- lożę aseptyczną (wys. 131,5 cm, szer. $114 \mathrm{~cm}$, gł. 60,5 cm),

- biurko (wys. 79,5 cm, szer. $130 \mathrm{~cm}$, gł. $60 \mathrm{~cm}$ ).

26 Meble te zostały przeniesione do wiejskiej apteki w Osiu w Borach Tucholskich i następnie odkupione przez właścicieli apteki od Przedsiębiorstwa Zaopatrzenia Farmaceutycznego „Cefarm” w Bydgoszczy. Zob. Apteka „Pod tabędziem”, s. 82. 


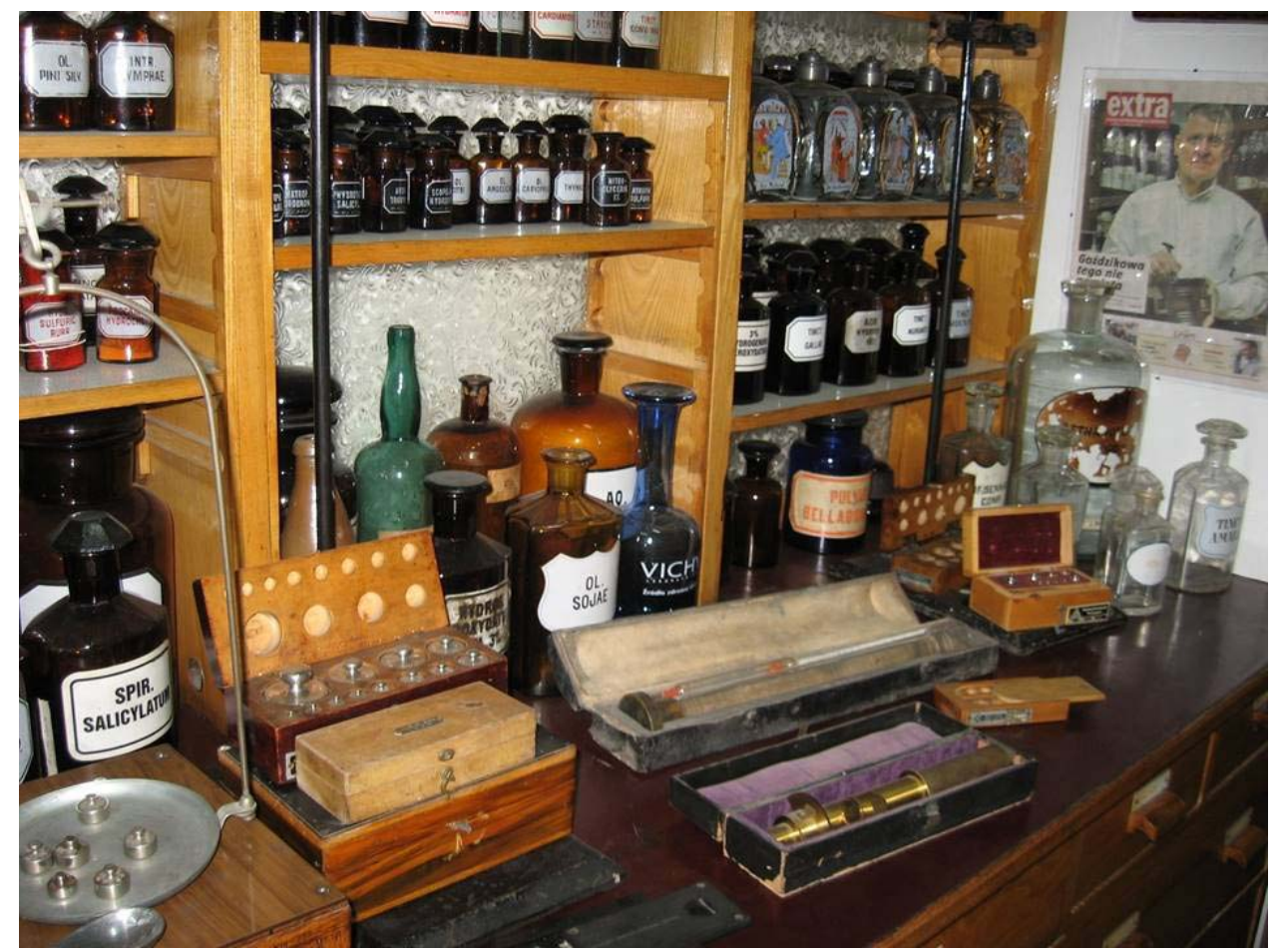

Ryc. 10. Receptura pełniąca funkcje magazynowe, ok. 2005 r. (fot. W. Ślusarczyk)

Zrezygnowano więc m.in. z loży szkoleniowej, stołu kontrolnego, destylatora, suszarki, promiennika podczerwieni do topienia podłoży maściowych, mieszadła elektromagnetycznego i czopkarki. Redukcja wyposażenia receptury wynikała z rosnącego udziału w obrocie aptecznym leków gotowych, wytwarzanych przez intensywnie rozwijający się globalny przemysł farmaceutyczny, wypierających leki recepturowe. W 2003 r., po powstaniu muzeum farmacji, izba recepturowa utraciła swoją pierwotną funkcję, stając się częścią stałej ekspozycji. Z czasem jednak zaczęła pełnić funkcję „magazynu” dla rosnącej liczby zabyt$k^{\prime} w^{27}$. Prywatne muzeum nie dysponowało bowiem przestrzenią magazynową (Ryc. 10).

Ponieważ w izbie recepturowej umieszczano przez kilka lat kolejne muzealia, ukazanie jej pierwotnego wyglądu i wyposażenia, a co za tym idzie - także funkcjonowania, jest zadaniem niezwykle trudnym. Pierwszy etap prac polegał na oddzieleniu zabytków, które można powiązać z pracą w recepturze od obiektów o innym charakterze. W chwili przejęcia apteki przez MOB w pomieszczeniu tym znajdowało się 361 naczyń recepturowych. Sposób ich ustawienia na półkach i blatach loży recepturowych był całkowicie przypadkowy (Ryc. 11).

Uwagę zwracała różnorodność naczyń, pod względem kształtów i rozmiarów, pochodzących głównie z przełomu XIX i XX w., na co wskazuje oranżowe zabarwienie szkła²8.

27 Muzeum Farmacji Apteki „Pod Łabędziem” pozyskiwało zabytki poprzez zakupy oraz dary. Ze względu na swój prywatny charakter, placówka nie prowadziła w związku z tym żadnej dokumentacji.

28 I. Arabas, Res Pharmaceuticae. Muzeum Farmacji im. mgr Antoniny Leśniewskiej Oddział Muzeum Warszawy Katalog wystawy stałej, Warszawa 2017, s. 84-85. 


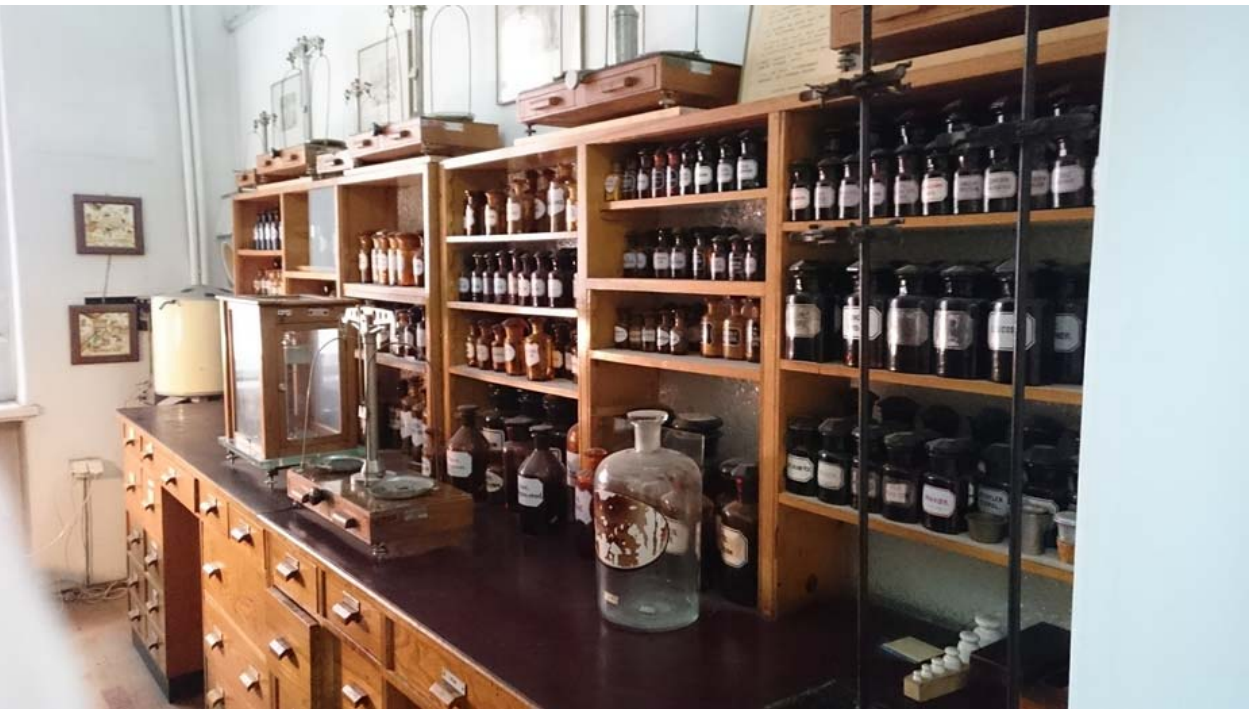

Ryc. 11. Receptura na początku 2019 r. (fot. R. Wilczyńska.

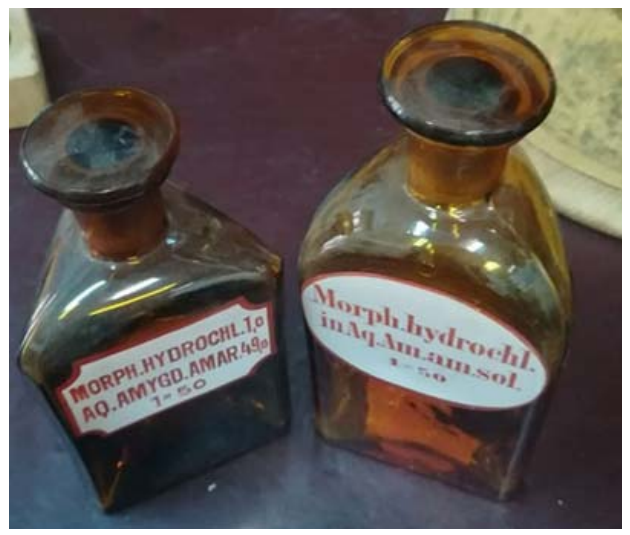

Ryc. 12. Przykładowe sztanglasy apteczne o nietypowym - trójkątnym - kształcie (fot. R. Wilczyńska)
Kilka butelek wykonanych zostało ze szkła bezbarwnego, co może sugerować ich pochodzenie z końca XIX w. Interesującym elementem różniącym butelki są kształty podstaw. Obok większości - czworokątnych, wyróżnić można również okrągłe czy trójkątne. Może wskazywać to na ich odmienne pochodzenie. Kierujący apteką zamawiał bowiem najczęściej w jednej, wybranej firmie cały zestaw naczyń, jednakowych pod względem stylistycznym. Różnorodny kształt naczyń może też jednak świadczyć o ich specyficznym przeznaczeniu, np. do przechowywania trucizn (Ryc. 12-14).

W przypadku naczyń recepturowych bardzo istotne jest odpowiednie ich oznaczenie. W przeszłości, jak i obecnie, powinno charakteryzować się ono czytelnym opisem zawartości. Wśród omawianych obiektów można wyróżnić różnorodne kształty tytulików (etykiet): okrągłe, czworokątne, ośmiokątne, a także bardziej skomplikowane wzory. Widnieją na nich łacińskie napisy. W piętnastu przypadkach są one sporządzone w języku niemieckim²9. Część etykiet jest słabo widoczna lub nieczytelna. Podobnie jak w przypadku kształtu naczyń rozmaitość w zakresie form tytulików wskazuje na ich różnorodne pochodzenie.

W okresie PRL-u (oraz obecnie) izba recepturowa jako miejsce wykonywania leków miała charakteryzować się uporządkowaną i przemyślaną strukturą dotyczącą zarówno rodzaju i ilości składników służących do wykonywania leków, jak i sposobu ustawienia 
naczyń. Dokładna analiza substancji, które znajdowały się w muzealnej recepturze apteki „Pod Łabędziem”, wskazuje na chaos w tym zakresie. W podobnie przypadkowy sposób poukładane były naczynia. Przykładem może być przemieszanie naczyń przeznaczonych do tak zwanej loży „mokrej” z naczyniami zarezerwowanymi dla loży "suchej” („proszkowej”). Nie przestrzegano również zasady, że roztwory stosowane do wyrobu leków powinny znajdować się na innych półkach niż substancje stałe. O braku porządku świadczy również ustawienie na jednej półce naczyń z substancjami z różnych wykazów farmakopealnych. W Farmakopei Polskiej IV, t. 2, z 1970 r. wyróżniono trzy wykazy leków. Do wykazu A należą substancje bardzo silnie działające, do wykazu B - silnie działające, natomiast

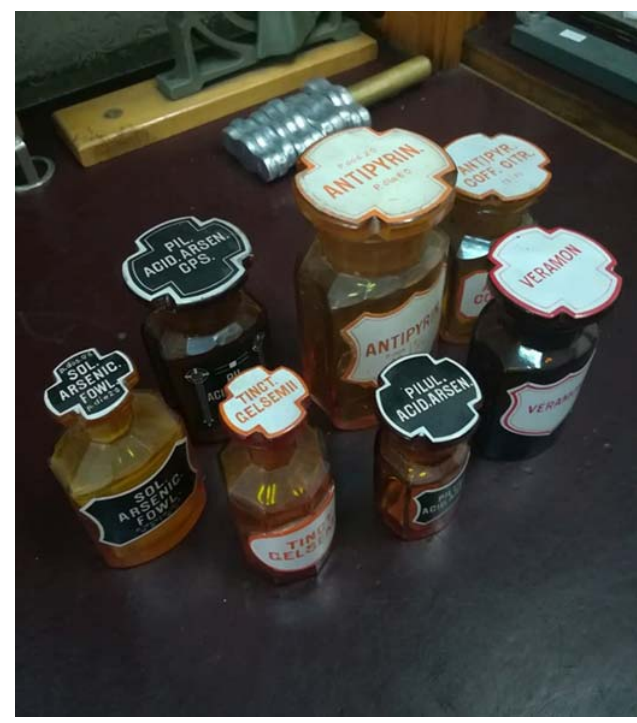

Ryc. 13. Przykładowe sztanglasy apteczne o nietypowym kształcie - z powtórzeniem tytulika na korku, przez co unikano omyłkowej zamiany korka i zanieczyszczenia substancji (fot. R. Wilczyńska) do wykazu N - środki odurzające ${ }^{30}$. Przykładem mogą być stojące na jednej półce Hydrargum bichloratum z wykazu A, Ephedrini hydrochloridum z wykazu B czy Morphini sulfas z wykazu N ${ }^{31}$. Należy przy tym dodać, że ich nomenklatura jest zgodna z Farmakopeą Polską V, której tom 1 ukazał się w 1990 r. Naczynia te są więc młodsze niż PRL. Ponadto trucizny, które powinno umieszczać się w osobnej, zamykanej szafce, były na wyciągniecie ręki w sąsiedztwie glukozy czy wazeliny (Ryc. 16).

Po dokładnym przejrzeniu wszystkich naczyń dało się zauważyć powtarzające się nawet na kilku półkach te same substancje, co nie powinno mieć miejsca. Przypuszczać można, że jest to wynikiem zestawienia w pomniejszonej, muzealnej w recepturze naczyń używanych wcześniej przez kilkoro farmaceutów przed prywatyzacją apteki w 1990 r. Biorąc to wszystko pod uwagę, należy stwierdzić, że obiekty zachowane $w$ recepturze nie mogą informować o rodzaju wykonywanych w niej dawniej leków.

Przeprowadzona analiza pozwoliła stwierdzić, że badane loże recepturowe zostały wyprodukowane najprawdopodobniej w Zasadniczej Szkole Drzewnej w Nowem nad Wisłą na przełomie lat sześćdziesiątych i siedemdziesiątych XX w. Wtedy bowiem zainstalowano je jako nowe wyposażenie wyremontowanej apteki. Wpisywały się w ówczesny standard wyposażenia izb recepturowych w aptekach społecznych w Polsce. Loże były

30 Farmakopea Polska IV, t. 2, 1970, s. 794-798.

31 Podane przykłady leków należą do szczególnej grupy preparatów ze względu na swoje silne działanie. Sporządzanie leków recepturowych, w skład których wchodziły wspomniane substancje, wymagało dodatkowej uwagi ze strony farmaceuty. Stąd powinny być przechowywane przynajmniej na osobnych półkach, a w przypadku substancji z wykazu N - w zamkniętej na klucz szafce. Praktyka ta jest stosowana w aptekach również obecnie w odniesieniu do preparatów gotowych wydawanych z przepisu lekarza dla zminimalizowania pomyłki przy wydawaniu leku. 


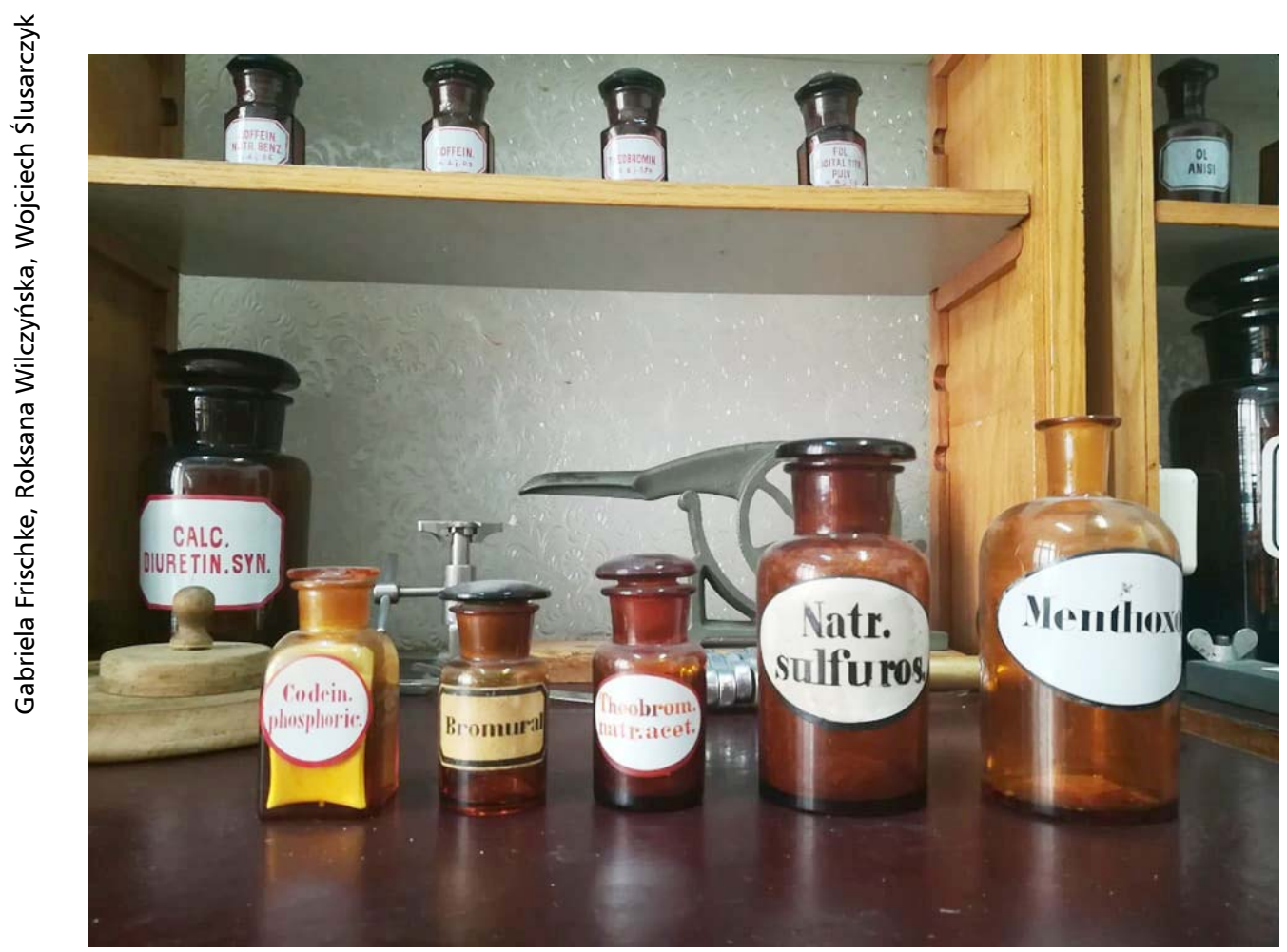

Ryc. 14. Przykładowe sztanglasy apteczne o różnych kształtach (fot. R. Wilczyńska)

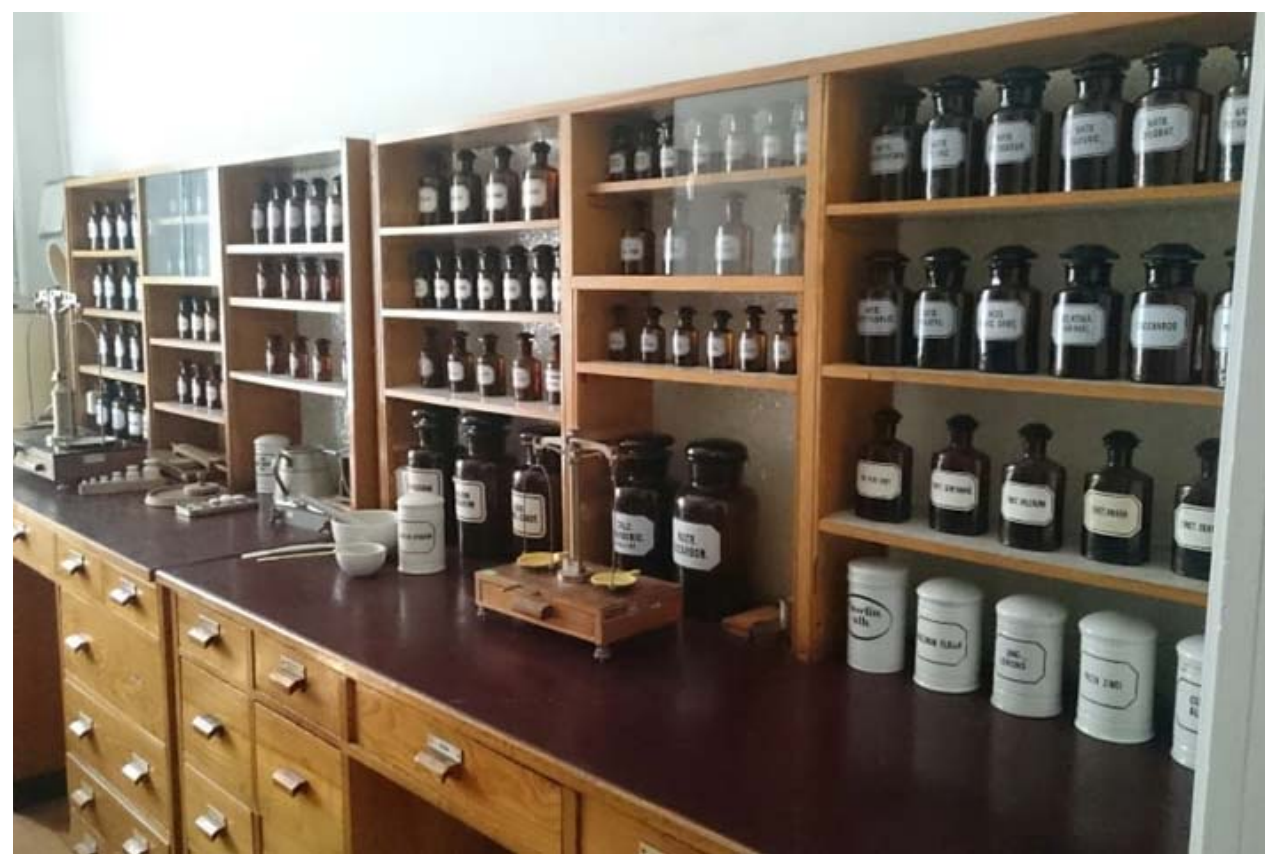

Ryc. 15. Propozycja aranżacji - odtworzenie standardu receptury z okresu PRL-u (fot. G. Frischke) 
używane wyłącznie w bydgoskiej aptece „Pod Łabędziem”, jednak pierwotnie znajdowały się w obszernym pomieszczeniu od frontu budynku. W obecne miejsce przeniesiono je w 1990 r., po reprywatyzacji przedsiębiorstwa. Relokacji towarzyszyło znaczne ograniczenie liczby mebli i sprzętów, co było spowodowane zmniejszeniem ilości wykonywanych leków recepturowych na rzecz gotowych specyfików wytwarzanych przez przemysł farmaceutyczny. Wyposażenie izby recepturowej nie jest kompletne i nie stanowi logicznej całości. Wchodzące w jego skład naczynia są niejednorodne pod względem czasu powstania oraz przeznaczenia. Sposób ich ustawienia nie odpowiada standardom pracy w recepturze. Panujący chaos sprawia, że zachowane obiekty nie mogą być odczytywane jako świadectwo mówiące o rodzaju wykonywanych leków. Izba recepturowa stanowi więc oryginalne wyposażenie apteki „Pod Łabędziem” z okresu PRL-u, zachowane jednak w okrojonej w 1990 r. formie, odpowiadającej zapo-

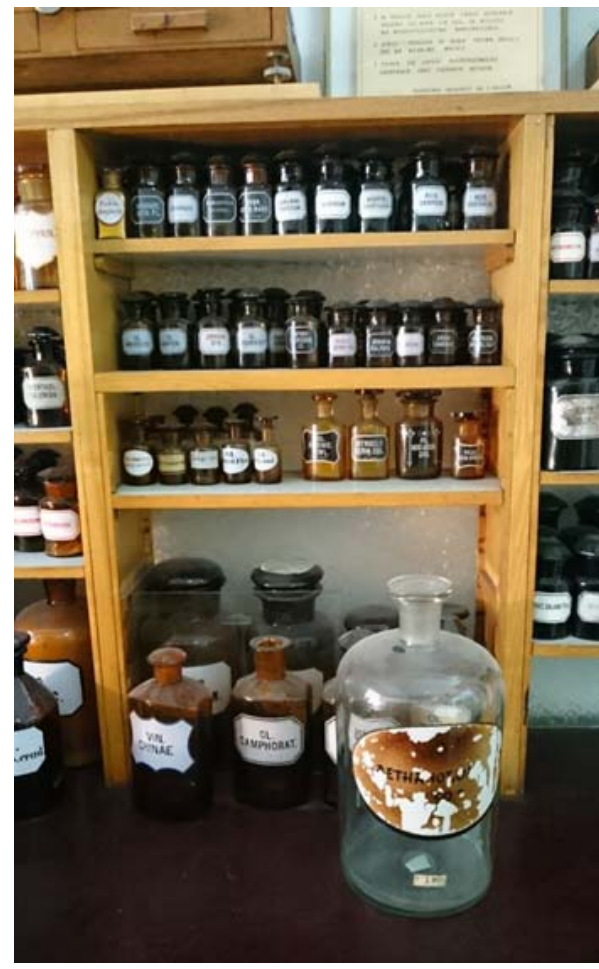

Ryc. 16. Przykład błędnego umieszczenia naczyń recepturowych przeznaczonych na trucizny (fot. G. Frischke) trzebowaniu typowemu dla wolnego rynku farmaceutycznego. Jej usytuowanie jest, jak wspomniano, wtórne. Wśród zachowanych naczyń panuje nieporządek. Nad genius loci przeważa więc wyraźnie suma przypadków. $Z$ tego powodu przygotowywana ekspozycja będzie musiała polegać w znacznym stopniu na odtworzeniu standardów panujących w recepturze z okresu Polski Ludowej (Ryc. 15).

\section{Bibliografia}

\section{Źródła archiwalne i muzealne}

Archiwum mgr farm. Łucji Wachowskiej (1945-1990).

Archiwum Państwowe w Bydgoszczy, Rejestr handlowy (1921-1942).

Zbiory Muzeum Okręgowego im. Leona Wyczółkowskiego w Bydgoszczy.

\section{Inne źródła}

\section{Farmakopea Polska IV, t. 2, Warszawa 1970.}

Sawrutin Z., Tajemniczy świat farmacji, „Ilustrowany Kurier Polski” nr 51, z 4 III 1980 r., s. 3. Ustawa aptekarska z 18 grudnia 1906 r., Austr. Dz. U. P. z 1907 r. No 5.

Ustawa dla farmaceutów i aptek, 1844 r., rozdz. IV, § 70, [w:] Ustawy dla farmaceutów i aptek. Dla materialistów. Dla kupców ukwalifikowanych do sprzedawania wszelkiego rodzaju towarów farbiarskich, Warszawa 1844. 
Zarządzenie ministra zdrowia w sprawie typów aptek, zakresu ich czynności, lokali i wyposażenia z 22 lutego 1956 r. „Monitor Polski” 1956 r., Nr 18, poz. 254.

Zarządzenie Ministra Zdrowia i Opieki Społecznej w sprawie typów aptek, zakresu i rodzaju czynności należących do aptek poszczególnych typów oraz wymogów dotyczących lokalu i wyposażenia aptek z 13 listopada 1992 r., "Monitor Polski” 1992 r., Nr 37, poz. 277.

Wywiad z Zenonem Gurbadą, pasjonatem historii meblarstwa, przeprowadzony 15 lipca $2020 \mathrm{r}$.

\section{Literatura przedmiotu}

Apteka „Pod Łabędziem” w Bydgoszczy. 150 lat, red. A. Drygas, Bydgoszcz 2003.

Arabas I., Res Pharmaceuticae. Muzeum Farmacji im. mgr Antoniny Leśniewskiej Oddziat Muzeum Warszawy Katalog wystawy stałej, Warszawa 2017.

Koskowski B., Nauka o przyrządzaniu leków i ich postaciach, t. 2, Warszawa 1929.

Kostrzeński L., Materjały do historji aptek wielkopolskich. T. 2, Apteki prowincjonalne, Warszawa 1936.

Majewski J., Muzea farmacji i zbiory aptekarskie w Polsce, Poznań 2006.

Schlick C., Apotheken in totalitären Staat. Apothekenalltag in Deutschland von 1937 bis 1945, Stuttgart 2008.

Szostak J., Farmakognozja, farmacja galenowa $i$ aptekarstwo $w$ renesansowych zielnikach polskich, Warszawa 2006.

Ślusarczyk W., Muzeum Farmacji Apteki „Pod Łabędziem” w Bydgoszczy, „Kwartalnik Historii Kultury Materialnej" t. 53, 2005, s. 124-125.

Ślusarczyk W., Chyła D., Przemysł chemiczno-farmaceutyczny na Kujawach i Pomorzu Gdańskim (1918/20-1950), Bydgoszcz 2017.

Urdang G., Kremers E., History of Pharmacy, red. G.A. Sonnedecker, Madison 1986.

Wajda K., Przeobrażenia gospodarcze Bydgoszczy w latach 1850-1914, [w:] Historia Bydgoszczy, t. 1, red. M. Biskup, Warszawa - Poznań 1991, s. 505-529.

\section{Zasoby internetowe}

Apteka „pod Łabędziem”, strona internetowa Szlaku Wody, Przemysłu i Rzemiosła $\mathrm{TeH}_{2} \mathrm{O}$, ludzieitechnika.pl/10-teh2o-apteka-pod-labedziem [dostęp 14.08.2019].

Historia Medycyny i Farmacji, strona internetowa Muzeum Okręgowego im. Leona Wyczółkowskiego w Bydgoszczy, muzeum.bydgoszcz.pl/zbiory/106,10920,0,0,DzialHistorii-Medycyny-i-Farmacji,1 [dostęp 14.08.2019].

mgr Gabriela Frischke, historyczka, doktorantka na kierunku historia na Wydziale Historycznym Uniwersytetu Kazimierza Wielkiego w Bydgoszczy. Adiunkt w Dziale Historii Medycyny i Farmacji Muzeum Okręgowego im. Leona Wyczółkowskiego w Bydgoszczy. Specjalizuje się w historii medycyny i farmacji oraz historii kultury i obyczajowości nowożytnej Polski, szczególnie 2 poł. XVIII w. Członkini Polskiego Towarzystwa Farmaceutycznego. Prezes Zarządu Fundacji Naukowej „Bydgoska Szkoła Historii Nauk Medycznych".

e-mail: gabriela.frischke@muzeum.bydgoszcz.pl 
mgr farm. Roksana Wilczyńska, przewodnicząca Sekcji Historii Farmacji Oddziału Bydgoskiego Polskiego Towarzystwa Farmaceutycznego. Członkini Polskiego Towarzystwa Historii Nauk Medycznych oraz Zarządu Fundacji Naukowej „Bydgoska Szkoła Historii Nauk Medycznych". Obszar jej zainteresowań obejmuje historię farmacji i medycyny. Współredaktorka serii wydawniczej Medyczne i kulturowe aspekty na przestrzeni dziejów.

e-mail: roka.wil19@gmail.com

dr Wojciech Ślusarczyk, historyk, absolwent Wydziału Humanistycznego Uniwersytetu Kazimierza Wielkiego w Bydgoszczy. Kierownik Działu Historii Medycyny i Farmacji Muzeum Okręgowego im. Leona Wyczółkowskiego w Bydgoszczy. Specjalizuje się w historii polskiego aptekarstwa. Członek Polskiego Towarzystwa Farmaceutycznego, Polskiego Towarzystwa Historii Nauk Medycznych, Bydgoskiego Towarzystwa Naukowego, Stowarzyszenia Historyków Sztuki, Stowarzyszenia Muzealników Polskich oraz Rady Muzeum przy Muzeum im. Jerzego Dunin-Borkowskiego w Krośniewicach. Współzałożyciel Fundacji Naukowej „Bydgoska Szkoła Historii Nauk Medycznych".

e-mail: wojciech.slusarczyk@cm.umk.pl

Data zgłoszenia artykułu: 20 maja 2020

Data przyjęcia do druku: 20 lipca 2020 